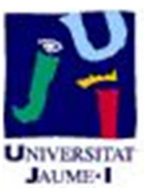

Título artículo / Títol article: Aesthetics of Resistance in Western Sahara

Autores / Autors Jennifer M. Murphy, Sidi M. Omar

Revista: $\quad$ Peace Review: A Journal of Social Justice

Versión / Versió: $\quad$ Versión Post-print

Cita bibliográfica / Cita MURPHY, Jennifer M.; OMAR, Sidi M. Aesthetics

bibliogràfica (ISO 690): of Resistance in Western Sahara. Peace Review, 2013, vol. 25, no 3, p. 349-358.

url Repositori UJI: $\quad$ http://hdl.handle.net/10234/114962 


\title{
Aesthetics of Resistance in Western Sahara
}

\author{
JenNifER M. MurPhy AND Sidi M. OMAR
}

In reaction to neo-liberal globalization policies that were spearheaded in the 1980s by Reagan-economics and Thatcherism, indignant movements ignited globally in distinct places, spaces, and territories, using diverse resistance

5 strategies, both violent and nonviolent. Today, two years into the new social media revolutions, with the "Arab Spring" (in Tunisia known as Sidi Bouzid Revolt, in Libya as the Revolution of February 17th, and in Egypt as Revolution of January 25th), the "indignado/a" movement in Spain, and "Occupy Wall Street" in the United States, what does it mean to be "indignant"? Within 10 an interdisciplinary Peace Studies and Research context, how do we begin to talk about and theorize this (inter)subjective move from being a "victim" to being "indignant?" And, how do we do so in a way that captures the complex and multi-layered dimensions of liberation struggles? We begin with a theoretical overview in order to frame the discussion. We then specifically

15 examine the "Sahrawi Spring" in order to see theory in practice. As Africa's last colony, Western Sahara provides an interesting look into the aesthetics of resistance.

T f Brazilian educator, philosopher, and influential figure of critical pedagogy, Paulo Freire, were alive today he might designate this move from victim to indignant as the necessary awakening of the oppressed. In his well-known book, Pedagogy of the Oppressed (first published in 1968), Freire declares that "the oppressed" are agents of their own recovery and must position themselves consciously and critically in the face of their problems and oppression. In his view, the pedagogy of the oppressed is one that engages in the struggle for personal and collective liberation, where the oppressed unveil the world of their oppression and engage in practice with its transformation. He stresses that it is only in "praxis," which involves both action and reflection over oppressive social, cultural, political, and economic structures, that "the oppressed" can transform the world in which they live. This transformation is a process of permanent liberation and requires a reformulation of education systems from a banking method (depositing information) to a critical engagement with knowledge and its production. 
Freire gives us some valuable analytical tools for exploring oppression and the state of victimhood, but his analysis is in many respects particular to his context and fails to reflect the complexities and layers inherent in diverse forms of oppression. He hints at the development of the concept of empowerment, which emerged in feminist studies in the 1990s, but does not break from the basic dichotomy of oppressed-oppressor. Black feminist, author, and social activist, bell hooks, works from Freire's critical pedagogy (thinking) theory and practice, and develops it further by introducing the idea of imperialist capitalist white-supremacist culture in order to reflect the interconnections of race, capitalism, and gender. This concept of intersectionality, coined by critical race theorist Kimberlé Crenshaw and further developed by black feminist epistemologist Patricia Hill Collins, explores the complex, interrelated, and overlapping forms of oppression constitutive of race, class, gender, nation, and sex(ualities). In the United States, black feminist and ethnic studies scholars introduced multiple ways of theorizing unequal power relations and oppression.

In parallel, but in reaction to Eurocentric epistemologies, LatinAmerican scholars Aníbal Quijano and Walter Mignolo contest simplistic binary oppressed-oppressor relationships through a postcolonial critique of power relations. Fundamental to Quijano's argument is the idea that the colonial model of power specifically organizes and structures the world's population around the idea of race and rationalizes this systematic construction of global power around one origin, Eurocentrism. According to Quijano, this racial axis has a colonial origin and character that has proven more durable and stable than the colonial system in which it was engineered. Therefore, today's globally hegemonic model of power contains by extension an element of coloniality, what he terms more broadly the "coloniality of power." The main signifier of this colonial mode of power is white, male, and European and the structure of power globally continues to be organized around the colonial axis. This modern/colonial world, Walter Mignolo's term for capturing unequal power relations, no longer consists of direct colonial rule and administrations (with the exception of 16 non-self-governing territories), but depends on systemic colonial continuities. Ramón Grosfuguel expands on both these concepts by linking them more completely to global capitalism. He explains that Quijano's concept of coloniality is absolutely situated in global capitalist structures - the international division of labor, global racial/ethnic hierarchies, and the hegemonic Eurocentric epistemologies. Grosfoguel adds that the colonial axis persists and perpetuates relations of economic exploitation, domination, and sanctions that produce particular Euro-"American" subjectivities and knowledges about the "modern" world.

In her critique of the coloniality of power, Argentinian philosopher María Lugones provides the theoretical bridge that links postcolonial 
conceptualizations of unequal power relations and the intersectionality analysis of U.S. black feminists. If coloniality functions as a complex matrix linking modernity, colonialism, capitalism, and racism, it is incomplete as long as gender remains unnamed and unchallenged. Although Lugones affirms the conceptual applicability of Quijano's coloniality of power, she constructively critiques his narrow understanding of the oppressive modern/colonial scope of gender. Lugones suggests that the coloniality of power assumes the patriarchal, heterosexual, and biological underpinnings of social relations as prescribed by the modern/colonial system, thereby accepting and perpetuating the global, Eurocentered, capitalist understandings of gender. In its stead, she proposes the modern/colonial gender system to refute the idea that gender arrangements are heterosexual, patriarchal, and bimorphic, and to confirm gender's colonial heritage. By doing so, she upholds the importance of Quijano's approach and at the same time underscores the intersections of race, class, gender, and sexuality(ies). She fuses gender and race in such a way that women of color are actually seen, and systemic racialized gender violence is revealed: Race is no more mythical and fictional than gender, both powerful fictions.

$\mathrm{B}$ $y$ intentionally bringing together intersectionality and the coloniality of power/gender, we have theory that better reflects the complexities of unequal human social, political, economic, and cultural relationships. Barbara Christian calls this complexity variousness, the multiplicity of experience, of being, and of feeling one's being. She also warns, however, against the drive to develop theory. Like Freire, she criticizes theory that has no link to practice; theory that determines which ideas are deemed valuable; theory that fails to illuminate or explain; theory that tends toward monolithic simplifications and generalizations; theory that mystifies (through linguistic jargon) rather than clarifies; theory that makes the world smaller, rather than reflecting a world that is large, complicated, and as sensual as it is experienced by marginalized peoples. She cringes at the sheer ugliness of the sterile language of theory, its lack of clarity, its complicated sentence structures, its lack of pleasurableness and its alienating qualities. While reading such "critical" theory she longs for the integration of feeling/knowledge. She tells the story within a creative complexity that is quite different from the Western form of abstract logic. This version, familiar to many people of color, plays out in narratives, stories, hieroglyphs, riddles, proverbs, and word games and, always, in constant and dynamic movement.

For Christian, like Freire, theory must be rooted in practice so it does not become prescriptive, exclusive, and elitist. This critique of theory per se, raises a new question, quite distinct from our original one. Our original question was, "What does it mean to move from being a 'victim' to being 'indignant'?" Now 
we must add: How can we achieve a more multidimensional understanding of how the oppressed, the "victim," moves in different ways in indignant 105 resistance? Thus, our discussion must go beyond theory with its dehistoricized and "un"-situated analysis and take into consideration the varied, complex, and overlapping systems of oppression and inequality (framed in intersectionality and the coloniality of power/gender concepts).

The edited work of Christa Davis Acampora and Angela L. Cotton Unmaking Race, Remaking Soul: Transformative Aesthetics and the Practice of Freedom, with explicit tribute to Gloria Anzaldua's collection Making Face, 110 Making Soul, offers a framework for discussion that is at once more complex and more grounded, inviting both theory and praxis. This framework explores social and political modes of expression that go beyond conventional intellectual and cognitive perspectives - ways of seeing, knowing, and understanding lived experience. It offers the concepts of aesthetic agency and transformative 115 aesthetics as the practice of freedom. This refers to our creative capacities in action and the multiplicity of possible social expressions and movements. It embraces difference and recognizes our diverse capacities for making and remaking the symbolic forms that shape our understandings of knowledge(s) (its acquisition, transmission, production, and reproduction). It also opens up 120 new ways of considering and reconsidering social structures, relationships, and how the world might possibly be negotiated, reorganized, contested, and created. This more holistic approach sharpens our capacities of perception and cultivates our creative sensibilities (our aesthetic agency) so that we can enter diverse spaces for seeing, being, and feeling our place(s) in our par- 125 ticular social, political, and cultural contexts, while at the same time look at resistance struggles relationally, in critical relationality. Aesthetic agency as a practice of freedom seeks to transform and transcend established oppressive situations that, even when critiqued, tend to designate "the other-victim" as inferior, deficient, and less-than. Thus, aesthetic agency is an analytical model 130 that also directly relates to conflict transformation processes and our abilities to act creatively and politically.

Here, we are reminded of the connection between aesthetics and education on the one hand and our practice of freedom as political, resistive, and creative political acts on the other. These sites of political and creative contestation as well as creation are cultural spaces for nurturing the imagination in spite of social and political structures and institutions that limit and defy 135 our capacity to imagine new ways of being in the world. As developed in his trilogy, Freire saw this as movement from oppression to hope to indignation. Vicent Martínez Guzmán, in his philosophy for making peace(s), applies this same trinity to the peaceful transformation of interpersonal and international conflicts by empowerment of "the excluded," but from their own perspective 140 of victim-victimization. Exploration of our sensual and creative capacities presents possibilities for transformative aesthetics to merge with a peace 
studies perspective of nonviolent conflict transformation in its multiple forms of expression.

A gainst this theoretical-practical backdrop, we shall now examine how

the "Sahrawi Spring" unfolded. We focus on the Gdeim Izik protest camp as a turning point in the sociopolitical process in which thousands of Sahrawi victims of all types of violence collectively transformed themselves into indignants and active agents of nonviolent resistance against occupation. In particular, emphasis will be placed on the significance of the Gdeim Izik protest camp and the key factors that framed this transformation process.

Many analysts consider Mohamed al-Bouazizi's act of self-immolation on December 17, 2010 the triggering event that sparked the mass revolts in Tunisia, which then spread to North Africa and the Middle East and came to be known internationally as the "Arab Spring." There was, however, another significant mass uprising in North Africa that went almost unnoticed (or ignored) by international and Arab media. Some analysts, such as Noam Chomsky, have described this mobilization as the catalyst for the "Arab Spring."

In October 2010, a few weeks before the tragic incident of al-Bouazizi in Tunisia, thousands of Sahrawis set up an unprecedented, peaceful protest camp in Gdeim Izik, to the east of La Aaiun in Moroccan-occupied Western Sahara. This camp was erected in protest against the precarious socioeconomic conditions and political marginalization in which Sahrawis have lived for over 35 years of Moroccan occupation. Some estimates suggest that the camp was 160 made up of eight thousand tents in order to house more than thirty thousand people. Despite the lack of adequate infrastructures and resources and the chaotic situation during the first days, the protestors managed to organize themselves by putting in place committees that catered to the basic needs of the participants. They provided food and water, health, sanitary chores, security, and negotiation.

The entire move came as a surprise to Moroccan authorities. They did not expect such a massive turnout of people or their determination to stay at the campsite for one-month's time. When Moroccan authorities realized the real purpose of the protestors, they immediately cordoned off the area, placing police and armed forces in strategic areas around the camp to prevent people from entering or leaving. Despite persistent provocations by Moroccan forces, the protestors remained determined to maintain the nonviolent character of their protest. Even when on October 24, 2010 Moroccan forces fired at a car heading to the camp and killed 14-year-old Nadjem Mohamed Fadel Gharhi, the protestors demonstrated self-restraint and refused to retaliate with violence. After a series of negotiations with representatives from the camp, in which Moroccan senior officials tried to persuade them to put an end to their protest, the authorities resolved to 
dismantle the camp and disperse its residents by force. This decision led to hundreds of injuries, some extremely serious, and to the destruction of property.

$I^{t}$

$\mathrm{t}$ is pertinent to underline that Sahrawis in the Moroccan-occupied Western

Sahara live predominately in conditions marked by poverty, high rates of unemployment, marginalization, and deprivation of their basic socioeconomic and political rights. Furthermore, the Moroccan authorities have flooded the territory with thousands of Moroccan settlers, thus converting the indigenous population into a minority in its own country. The Moroccan authorities have also engaged in a policy of "moroccanization," which is aimed at obliterating or supplanting Sahrawi culture and heritage. Moroccan authorities continue to ban the use of hassaniya, the Sahrawi dialect, or any display of Sahrawi distinct culture, while encouraging the use of Moroccan dialects in the education system and public institutions.

The significance of the Gdeim Izik camp, therefore, is not only located in the establishment of the camp in and of itself or in the peaceful character of the protest. It also lies in the interplay of the discursive, spatial, and sociocultural dimensions of this unprecedented and creative act of mass protest. At the 190 thematic level, the discursive shift that took place in terms of the nature of the demands of the demonstrators and how they were articulated during the various stages of the protest marks the import of the protest camp. The camp started as a spontaneous and unplanned act, but gradually transformed into a mass demonstration of collective action. Tens of thousands of Sahrawis from all walks of life participated in what became an extended organized protest to make public their demands. The transformation of the camp was paralleled by a gradual and largely planned discursive shift from seemingly non-political, socioeconomic demands to overtly political claims.

As indicated earlier, Sahrawis in the Moroccan-occupied Western Sahara have for decades shared collective experiences of repression, marginalization, and dispossession. The majority of them have been victims of various forms 200 and degrees of violence and mainly for political reasons. As a collective act of protest and resistance, the Gdeim Izik camp reinforced the attachment of the protestors to their Sahrawi national identity. This active form of political commitment was then reflected in the public reaffirmation of Sahrawi identity and support for the self-determination and independence of Western Sahara.

Another key element of the Gdeim Izik protest camp is its spatial dimension, reflected in the place that was chosen for staging the mass protest. 205 Setting up the camp on the outskirts of a major urban center in occupied Western Sahara avoided any disturbance of "the public order," as the protestors made clear from the beginning. At the same time, the act bore a particular political and symbolic significance. The protestors clearly wanted to distance themselves from the mechanisms of control associated with urban centers 210 
and their officially imposed public order. These methods represented the continuous occupation of the territory and the related deprivation of the basic socioeconomic and political rights of its population. Moreover, the protestors sought to go beyond the traditional spaces of struggle and create a new space, loosely controlled by state authorities, from which they could mount their acts of protest and resistance.

$\mathrm{T}$

he importance of the Gdeim Izik protest camp also lies in the typically Sahrawi sociocultural setting in which it was set up. In planning their camp, the protestors were largely inspired by the nomadic culture of Sahrawi society, where the jaima (traditional tent) is a central element and a recognizable symbol of Sahrawi culture. The way participants organized their tents was reminiscent of the traditional forms of "Lefriq," the gathering of tents. In this tradition, tents are placed in close proximity to each other, allowing for smooth interactions between the inhabitants of the camp and ensuring their collective security. By appropriating the jaima as a symbol of rootedness and attachment to the land, the protestors sought to emphasize not only their cultural and identitarian distinctiveness, but also the underlying political overtones of their mass protest

Together with its discursive, spatial, and sociocultural dimensions, the Gdeim Izik protest camp was also characterized by the massive participation of Sahrawis from different sectors of society. Youth groups and women were particularly instrumental in mobilizing and organizing the protest and in supervising and responding to the day-to-day needs of the demonstrators. The active participation of the youth in this mass protest is particularly significant, given that many of them were born into occupation and have been schooled in Moroccan assimilationist ideology. In their paper, "The Nonviolent Struggle for Self-Determination in the Western Sahara," Stephen Zunes and Salka Barca point out that the younger generation of Sahrawis who grew up under Moroccan occupation appears to be as strongly in favor of independence as their parents. In their view, this is perhaps a reflection of family heritage as well as the personal experience of living under oppressive, military rule, where most families have had a member killed, jailed, or disappeared.

The Gdeim Izik protest camp emerged out of a cumulative process of sociopolitical transformation brought about by the internal dynamics of continuous resistance to repression. Sahrawis have learned to redefine and diversify their methods of resistance with the aim of generating new spaces through which they can voice their grievances and assert their sociopolitical demands. In fusing sporadic and individual actions of protest against repression into an overt act of collective resistance, the Gdeim Izik camp provided a wider space for Sahrawi victims of all types of violence to empower and transform themselves collectively into indignants and political actors engaged in new discourses, debates, and actions of nonviolent resistance. 
$I^{\prime}$

$\mathrm{n}$ his widely cited book, The Wretched of the Earth, Frantz Fanon argues

that violence claimed by the colonized had a liberating or "cathartic" effect in that it offered a primary form of agency through which the colonized moved from being mere passive victims and objects of colonial violence to active subjects of anticolonial resistance. Obviously, Fanon was speaking from a particular time and space, and his analysis of violence was focused 250 primarily on the dialectic between the colonizer and the colonized and their relationship that was born and perpetuated through various modalities of colonial violence. In The Ethics of Ambiguity, Simone de Beauvoir states, "For freedom wills itself genuinely only by willing itself as an indefinite movement through the freedom of others." The ambiguity to which she refers lies in the tension intrinsic to a freedom struggle that is always to come and always an indefinite movement, involving not just one, but many. Fanon's framework is a version of the coloniality of power, and de Beauvoir's ambiguity can be viewed as an effort to capture a sense of the aesthetic. The case of Gdeim Izik protest camp, however, goes beyond Fanon's argument and inverts its 260 logic in a way to demonstrate that by engaging in nonviolent activism, the colonized can become active agents of anticolonial resistance. The camp also demonstrates the aesthetics of resistance, discussed earlier, in ways that enrich Beauvoir's ambiguity by reflecting the complex and intersectional inequalities, the matrixes of domination and exploitation, and the power of multiple/various agencies.

In order to understand, imagine, and create outside-imposed limitations, the participants in the Gdeim Izik protest camp turned to the possibilities offered by diverse aesthetic agencies, and transformed layers of oppression, rooted in colonialism, into indignant response. They ushered in a new era of heightened national and political engagement in Moroccan-occupied Western Sahara. It is still to be seen whether this political activism will translate into 270 more vigorous and innovative forms of nonviolent struggle to end Africa's last colonial conflict. Nonetheless, the camp stands as a powerful example of movement from being a victim to being indignant. The "Sahrawi Spring" demonstrates the powerful possibilities of aesthetic agency and nonviolent political action-the on-the-ground move from occupied to creative nonviolent 275 indignant resisters. It is in such creative action and practice of freedom that we see how struggles for social and political change and against inequality are constantly being made and unmade.

\section{RECOMMENDED READINGS}

Acampora, Christa Davis and Angela L. Cotton. 2007. Unmaking Race, Remaking Soul, Transformative Aesthetics and the Practice of Freedom. Albany: State University of New 280 York Press.

Anzaldúa, Gloria. 1990. Making Face, Making Soul Haciendo Caras: Creative and Critical Perspectives by Women of Color. San Francisco: Aunt Lute Foundation Books. 
Barca, Salka and Stephen Zunes. 2009. "The Nonviolent Struggle for Self-Determination in Western Sahara." In Maria J. Stephen (ed.), Civilian Jihad: Nonviolent Struggle, Democratization, and Governance in the Middle East. New York: Palgrave.

Crenshaw, Kimberlé. 1991. "Intersectionality, Identity Politics, and Violence against Women of Color." Stanford Law Review 43(6): 1241-1299.

Crenshaw, Kimberlé. 2004. "Instersectionality: The Double Bind of Race and Gender," Interview, American Bar Association, Spring.

Freire, Paulo. 2000. Pedagogy of the Oppressed. New York: Continuum.

Freire, Paulo. 1994. Pedagogy of Hope: Reliving Pedagogy of the Oppressed. New York: Continuum.

Freire, Paulo. 2004. Pedagogy of Indignation. Boulder, CO: Paradigm Publishers.

295 Grosfoguel, Ramón. 2008. "World-System Analysis and Postcolonial Studies: A Call for a Dialogue from the 'Coloniality of Power' Approach.” In Revathi Krishnaswamy and John C. Hawley (eds.), The Postcolonial and the Global. Minneapolis: University of Minnesota Press.

Hill Collins, Patricia. 2000. Black Feminist Thought: Knowledge, Consciousness and the Politics of Empowerment. New York: Routledge.

hooks, bell. 1981. Ain't I a Woman: Black Women and Feminism. Boston, MA: South End Press.

hooks, bell. Teaching Critical Thinking: Practical Wisdom. New York: Routledge.

Human Rights Watch. 2013. Human Rights Watch World Report 2013: Events of 2012. New York: Seven Stories Press.

Lugones, María. 2008. "Coloniality of Gender.” Words and Knowledges Otherwise (Spring).

Martínez Guzmán, Vicente. "Discurso y sensibilización: Entre La indignación y la esperanza." In Vicente J. Benet and Eloísa Nos Aldás (eds.), La publicidad en el Tercer Sector: Tendencias y perspectivas de la comunicación solidaria. Barcelona: Icaria.

310 Mignolo, Walter D. 2000. Local Histories/Global Designs: Coloniality, Subaltern knowledges and Border Thinking. Princeton, NJ: Princeton University Press.

Mignolo, Walter D. 2000. "The Many Faces of Cosmo-Polis: Border Thinking and Critical Cosmopolitanism.” Public Culture 12(3): 721-748.

Mignolo, Walter D. 2008. "The Logic of Coloniality and the Limits of Postcoloniality."

315 In Revathi Krishnaswamy and John C. Hawley (eds.), The Postcolonial and the Global. Minneapolis: University of Minnesota Press.

Murphy, Jennifer M. 2012. "A Transnational Politics of Mobility. Thinking From and Across Borders.” In Angela Pilch Ortega and Barbara Shrottner (eds.), Transnational Spaces and Regional Localization: Social Networks, Border Regions and Local-Global Relations. Münster: Waxmann.

Omar, Sidi M. 2012. "National Identity Formation in Transnational Spaces: The Case of the Sahrawis of Western Sahara.” In Angela Pilch Ortega and Barbara Shrottner (eds.), Transnational Spaces and Regional Localization: Social Networks, Border Regions and Local-Global Relations. Münster: Waxmann.

Quijano, Aníbal. 1993. "Raza, Etnia, y Nación, en Mariátegui: Cuestiones Abiertas.” In Roland Forgues (ed.), El Otro Aspecto del Descubrimiento. Lima, Perú: Empresa Editora Amauta.

Quijano, Aníbal. 1999. "Coloniality and Modernity/Rationality.” In Goran Therborn (ed.), Globalizations and Modernities, European and Latin American Experiences and Perspectives. Stockholm: Furksningradnamnden.

Quijano, Aníbal. 2000. "Coloniality of Power, Eurocentrism, and Latin America." Nepantla: Views from South 1(3): 533-580. 
Shelley, Toby. 2004. Endgame in the Western Sahara: What Future for Africa's Last Colony? London: Zed Books.

This essay forms part of the research projects CS02012-34066 and P1.1A2012-05 mentioned in the introduction of this issue.

Dr. Jennifer M. Murphy is a postdoctoral research fellow at the Interuniversity Institute of Social Development and Peace at Universitat Jaume I de Castellón. She holds a European Doctorate in Peace, Conflict and Development Studies. Her thesis, written and defended in both English and Spanish, recently received the PhD Extraordinary Award. She currently lectures on philosophy for peace, interculturality, aesthetics of difference and research strategies. When reading and writing, she puts on her postcolonial 340 and intersectionality lenses and opens her interdisciplinary research adventure to thinkers, theorists, and practitioners from cultural, ethnic, gender, and peace studies. Her website is: www.murphyjennifer.com. E-mail: jennimurf@gmail.com

Dr. Sidi M. Omar is a researcher and diplomat from Western Sahara. He has a Ph.D. in Peace, Conflict and Development Studies and he is currently a researcher at the Interuniversity Institute of Social Development and Peace of Universitat Jaume I of Castellón, Spain, where he lectures on peace, conflict, philosophy for peace, and cultural studies. His areas of research include peace, conflict and development studies, 345 post-colonial, cultural and discourse studies, Western Sahara, North Africa and Middle East politics. He has several publications on these topics in Arabic, English, and Spanish. E-mail: sidiomar@sidiomar.net 